\title{
【研究ノート】
}

\section{乱流の速度分布則について \\ ON THE VELOCITY DISTRIBUTION FUNCTION \\ OF TURBULENT FLOW}

椎 貝 博 美*

By Hiroyoshi Shi-igai

\section{1. 概 説}

乱流の速度分布をあらわす式としては, 対数法則と指 数法則がもっとも広く用いられてきている。しかし, 両 者の間の関係は, 筆者の知る限りにおいては, 未だ明ら かにされていない。また, 近代の乱流の統計理論の発達 は, 対数則の一つの基盤となっている混合距離理論の不 備を指摘し，その結果，なかば実験式のような意味にお いて対数法則をとりあつかう人が多い。

この論文では, 物理的な考察はある程度犠牲にして, 数式的な面から検討を行ない, 対数則と指数則閒の関係 を明らかにしようという試みがなされている。

物理性を犠牲にしているということは, この論文の抲 点であるが, 数式的な面においては, 対数法則と指数法 則がかなり近い関係にあることを示すことができた。

\section{2. 予備的な考察}

対数法則はよく知られているようにPrandtl あるいは von Kármán によって混合距離理論を元にして導かれた のが最初である。

指数法則, 特に $1 / 7$ 乗則は経験的に得られたものと思 われる。

その後, 乱流統計理論の発達により, 両者を次元解析 によって求めることがなされた よって得られる，といらことは一種の矛盾である。そこ でそれらについてなされている仮定の検討をも含めて， 簡単に次元解析による方法を述べておくことにもる。 まず，指数法則についてはつぎのとおりである。

$$
\begin{aligned}
& \text { 摩擦係数 } C_{f}=\frac{\tau_{0}}{\frac{1}{2} \rho U_{0}} \\
& \text { 摩擦速度 } U_{*}=\sqrt{\frac{\tau_{0}}{\rho}}
\end{aligned}
$$

式 (1), (2) は定義である。ここで, $\tau_{0}$ : 壁面における せん断応力, $\rho$ : 密度, $U_{0}$ : 自由流の遠度である。

つぎに， $C_{f}$ はレイノルズ数によって定まり，そのべ き采であらわされるものと仮定する。ゆえに，

$$
C_{f}=\frac{\text { const. }}{\left(\frac{U_{0} \delta}{\nu}\right)^{m}}
$$

ここに， $\delta:$ 壁から自由流までの距離

(1), (2), (3) から,

$$
\frac{U_{0}}{U_{*}}=\text { const. }\left(\frac{U_{*} \delta}{\nu}\right)^{m /(2-m)}
$$

つぎに，(4) の関係は壁より $\delta$ 以内の地点においても 成立するものとする。これから, 任意の $y<\delta$ において

$$
\frac{U}{U_{*}}=\text { const. }\left(\frac{U_{*} y}{\nu}\right)^{m /(2-m)}
$$

が得られる。つぎに, 大きな仮定として，U/U の関数で指数型であらわされるとする。この仮定は層流 においてはある程度正しい。しかし, 実は指数型の重ね 合せで得られる。乱流においては近似的な意味しかもた ない。式(5) のような形式がすでに得られているので, これと 3 番目の仮定から，

$$
\frac{U}{U_{0}}=\left(\frac{y}{\delta}\right)^{m /(2-m)}
$$

が得られる。 $m=1 / 4$ とおくと, つぎの一連の式が得ら. れる。なお, 定数は通常用いられている值を用いた。

$$
\begin{aligned}
C_{f} & =0.0466\left(\frac{U_{0} \delta}{\nu}\right)^{-1 / 4} \\
\frac{U_{0}}{U_{*}} & =8.74\left(\frac{U_{*} \delta}{\nu}\right)^{1 / 7} . . \\
\frac{U}{U_{*}} & =8.74\left(\frac{U_{*} y}{\nu}\right)^{1 / 7} \cdots \\
\frac{U}{U_{0}} & =\left(\frac{y}{\delta}\right)^{1 / 7} \ldots \ldots \ldots \ldots .
\end{aligned}
$$

つぎに対数法則のほうを調べよう。まず， $\tau_{0}, U, y, \nu$ の間に関数関係があるとすれば, 次元解析から,

$$
\frac{U}{U_{*}}=f\left(\frac{U_{* y}}{\nu}\right)
$$

が得られる。つぎに, 自由流の流速 $U_{0}$ と任意点の流速 $U$ との差はせん断力によって生ずるものと考え, $\delta, y$, $U_{*}$ によって定まるものとする。しかるときは,

$$
\frac{U_{0}-U}{U_{*}}=g\left(\frac{y}{\delta}\right)
$$

が得られる。式 (11)，(12）を書き直すと,

$$
\frac{U}{U_{*}}=f\left[\left(\frac{y}{\delta}\right)\left(\frac{U_{*} \delta}{\nu}\right)\right] \text {. }
$$




$$
\frac{U}{U_{*}}=\frac{U_{0}}{U_{*}}-g\left(\frac{y}{\delta}\right)
$$

唡式が満足されるためには， $f, g$ が対数関数でなくては ならないから, 通常用いられている形として, 次式が得 られる。

$$
\frac{U}{U_{*}}=\frac{2.3}{\kappa} \log _{e} \frac{U_{*} y}{\nu}+c_{1}
$$

上記二つの方法によってわかるように，諭旨はかなり はっきりしているが，やはり結果をあらかじめ知ってい なければ，とうてい導けるようなものではない。また指 数法則は，その仮定からして，層流状態に近いところ， すなわち, 比較的低いレイノルズ数において成立するこ とになるが，これは実測と一致している。

\section{3. 数式的な検討}

次元解析的な方法によっても，なお，指数法則と対数 法則間の関係は明らかではない。そこで，この節では著 者の考えた数式的な検討を行なら。

まず，せん断応力 $\tau$ と平均速度勾配との間にはつぎの 関係が成立するものとする。

$$
\tau=\rho \eta \frac{d u}{d y}
$$

ここで, ク は一般化された粘性係数で, その物理的意味 はしばらく問わないものとする。つぎに $て$ は次式で与え られると仮定する。

$$
\tau=\tau_{0}\left(1-c \frac{y}{\delta}\right) \quad c=\left\{\begin{array}{l}
1 \\
0
\end{array}\right.
$$

ただし， $c$ は 1 または 0 とする。 $c=1$ のときは, 開水路 のように $\tau$ が線型に変化する, という仮定になる。 $c=0$ のときは $\tau=\tau_{0}$ となり，境界層内の流れのような場合で ある。式 (16),(17) から，

$$
\frac{U_{*}{ }^{2}\left(1-c \frac{y}{\delta}\right)}{\eta}=\frac{d u}{d y}
$$

が得られる。またクは

$$
\eta=\eta\left(\frac{y}{\delta}, U_{*}, \delta\right)
$$

で定まると仮定する（ $\eta$ の次元は速度 $\times$ 長さ）。さらに

$$
\eta \sim U_{*}^{n} \delta^{m} y^{l}
$$

そおく。 $n=1, m+l=1$ で亩ることはすぐわかるので,

$$
\eta \sim U_{*} \delta\left(\frac{y}{\delta}\right)^{1-m}
$$

が得られる。 $1-m$ を改めて $n$ とかいて

$$
\eta=U_{*} \delta\left(\kappa \frac{y}{\delta}\right)^{n}
$$

が得られる。とくに $n=1$ とおくと $\eta=U_{*} \kappa y$ となって 混合距離理論と同じ仮定となる。ただし，几のおき方に は問題があって, もちろん $\eta=\kappa U_{*} \delta\left(\frac{y}{\delta}\right)^{n}$ とおくこと もできる。ただ式 (23) ようにおくと，多少便利な点が あるのでこのようにおいた。この式を式 (19) に代入す れば,

$$
\frac{d u}{d y}=\frac{U_{*}\left(1-c \frac{y}{\delta}\right)}{\delta\left(\kappa \frac{y}{\delta}\right)^{n}}
$$

が得られる。 $y / 0=\xi$ とおいて，無次元化を行なうと，

$$
\frac{d u}{d \xi}=\frac{U_{*}}{\pi^{n}}\left[\xi^{-n}-c \xi^{1-n}\right]
$$

が得られる。 $n \neq 1,2$ の場合, 積分すれば,

$$
\frac{U}{U_{*}}=\frac{1}{\kappa^{n}}\left[\frac{1}{1-n} \xi^{1-n}-\frac{c}{2-n} \xi^{2-n}+A\right]
$$

が得られる。また $n=1$ のときは，

$$
\frac{U}{U_{*}}=\frac{1}{\kappa}[\ln \xi-c \xi+B]
$$

が得られる。 $n=2$ のときも同様に，

$$
\frac{U}{U_{*}}=\frac{1}{\kappa^{2}}\left[-\xi^{-1}-c \ln \xi+B^{\prime}\right]
$$

となる。

式 (26) において, $n=6 / 7$ とおけば,

$$
\frac{U}{U_{*}}=\frac{7}{\kappa^{6 / 7}}\left[\xi^{1 / 7}-\frac{c}{8} \xi^{8 / 7}\right]
$$

が得られる。ただし， $\xi=0$ で $u=0$, すなわち $A=0$ と おいた。これは, 一応粘性底層を無視していることであ る。

式 (27) で $c=1$ とおくと, $\tau$ の変化を考慮した対数 法則が得られ， $c=0$ とおけ新， $\tau=\tau_{0}=$ 一定としたとき の対数法則となる。また, 式 (28) でも同様で,たとえば $c=0$ とおくと，1/7 采則忍得られる。このようにしてみ ると, 式 (23) において, $n=1$ とおくか, または 1 に 近い 6/7 とおくかによって, 式 (19)の基礎式から, 対 数法則, あるいは指数法則のいずれでも導けるのがわか る。したがって，数值的には，いずれによろうともそれ ほどの相異はないことが明らかである。いいかえると， もし,一つの実験值があって, 対数則にほぼ一致すれ ば，指数法則にも大体合うことが予想されるのである。 なお，式（26）で，たとえば $n=8 / 9$ とおけば $1 / 9$ 乘則 が得られるから，1/9 乗則は $1 / 7$ 乘則より対数法則に近 いことがわかる。

いま，試みに式 (28) で $y \div \delta$ 付近の様子を考えよう。 $y / \delta=1-\varepsilon(\varepsilon \ll 1)$ とおけば,

$$
\xi^{1 / 7}=(1-\varepsilon)^{1 / 7} \div\left(1-\frac{1}{7} \varepsilon\right) \div 1+\frac{1}{7} \log (1-\varepsilon)
$$

であるから， $\xi^{1 / 7} \div 1+\frac{1}{7} \log \xi$ であることがわかる。 $c=0$ について, 式 (28) に上記の関係を代入すると,

$$
\frac{U}{U_{*}}=\frac{1}{\kappa^{6 / 7}}\left[\log _{e} \frac{y}{\delta}\right]+\frac{7}{\kappa^{6 / 7}}
$$

が得られる。これは，指数法則を対数法則で近似したも

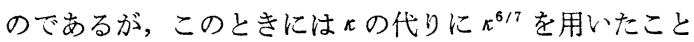
になる。もっとも， $\kappa$ が一定であるのか, $\kappa^{n}$ が一定であ るのか, それとも $\kappa$ も $\kappa^{n}$ も変化するのかということ は,このような方法からは定められない。いま，か门に $=0.4$ でこれが universal constant であるとすれば, 
$\kappa^{6 / 7}=0.46$ となる。つまり指数法則によるべきものを， 半対数紙上にプロットすれば, みかけ上, カルマン定数 が増大していることを示す。またこの議論を一般化す れば, 式 (26) を対数則で近似すると, このときのカル マン定数のみかけの值は $\kappa^{n}$ となるので, $n>1$ の場合 は，みかけ上カルマン定数が減少することになる。いい かえると, カルマン定数そのものが不変であっても, 速 度分布形が変化するとカルマン定数が変化したように観 測されることを示す。

物理的な考察は後に行なうことにして, もう少し, 式 （28）について調べよう。式（28）から平均流速 $\bar{U}$ は,

$$
\begin{array}{ll}
\frac{\bar{U}}{U_{*}}=\frac{6.125}{\kappa^{6 / 7}} & (c=0) \\
\frac{\bar{U}}{U_{*}}=\frac{5.71}{\kappa^{6 / 7}} & (c=1)
\end{array}
$$

で与えられ, $y=\delta$ における最大流速 $U_{0}$ は,

$$
\begin{array}{ll}
\frac{U_{0}}{U_{*}}=\sqrt{\frac{2}{c_{f}}}=\frac{7}{\kappa^{6 / 7}} & (c=0) \\
\frac{U_{0}}{U_{*}}=\frac{6.125}{\kappa^{6 / 7}} & (c=1)
\end{array}
$$

で与えられる。 $\kappa=0.4$ とおくならば，シエジー型の式， すなわち，

$$
\left.\begin{array}{ll}
\bar{U}=41 \sqrt{H I} & (c=0) \\
\bar{U}=38 \sqrt{H I} & (c=1)
\end{array}\right)
$$

が得られる。ただし， $U_{*}=\sqrt{g H I}$ とおいた。この值は $c$ の值の下限值にほぼ等しい。より一般にシエジーの $C$ 惊

$$
\begin{aligned}
C & =\frac{\sqrt{g}}{\kappa^{n}}\left(\frac{1}{1-n}-\frac{1}{2-n}\right) \\
& =\frac{1}{(1-n)(2-n)} \frac{\sqrt{g}}{\kappa^{n}} \quad(n \neq 1,2)
\end{aligned}
$$

の形式になる。ただし $n$ が 1 をこえることはできない。

\section{4. 総 括}

前節では数式上の議論を主として行なってきたが，こ の節においては多少物理的な考察も含めて総括を行な 5。

まず, 渦動粘性俰数 $\eta$ に関する仮定であるが, $\eta \sim y$ と いうことと, 混合距離理論において $l=\kappa y$ とおくこと はほぼ同様の仮定といえる。したがって，クについて他 少勝手な仮定をおくことは，lについて，仮定をおくの と同じことであるといえる。この限りにおいて，指数法 則と対数法則とは，非常に近い関係にあることが示され た。

式 (29) についてはつぎのように解釈できる。すなわ ち, 指数型の流速分布を与える式は, 管路の中心部, 開
図-1 指数法則と実測值の比較

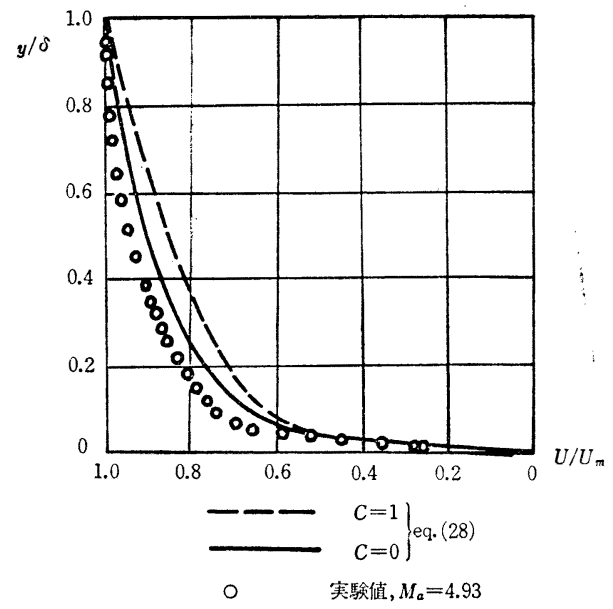

水路の水面付近, あるいは境界層の上部付近では対数式 で近似できる。ただし， $ぇ$ の值はみかけ上変化する。こ のような場合は壁面付近で数数則からはずれるはずであ る。

式 (31) から， $\kappa^{n}$ が減少すれば $c_{f}$ の值も減少する。 このことは過去の実験で知られている。しかしこのと き，むし $U_{0}$ が一定とすれば $U_{*}$ が減少することにな り，実験事実と反する。

せん断応力 $\tau$ が線型に変化するときと, $\tau=\tau_{0}=$ const. とおいた場合の流速分布形式の相違はそれほど大きいも のではない。たとえば, 式 (27) で $c=1$ とした場合で も $c=0$ とした場合でもそれほど大きな差を生じないの はよく知られている。図一1 は境界層内での速度分布の 実測值の一例 $\left.{ }^{2}\right)$ と, 式 (28) で $c=1, c=0$ とした場合の 比較を示す。これから，開水路において $\tau \doteqdot \tau_{0}$ と近似的 においた式でも一応実測值と一致する理由の一部がわか った。

このような方法による解析は, 結局すべての不明な点

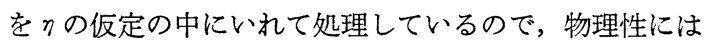
非常に乏しい。しかし, 乱流の統計理論等においても， たとえば，対数則を正しいものとして採用し，さらにそ の微分等も用いられているという点において, 数式的な 見地からは扱かい方にそれほどの物理性はないといえ る。その意味において，この論文は，対数則と $1 / 7$ 乗則 の同価性を論じたものである。

\section{参考 文 献}

1) Schubauer, G.B. and Tchen, C.M. : Turbulent Flow, Princeton Univ. Press, 1961

2) Lobb, K.R., Winkler, E.M., and Persh, J. : J. Aeronaut. Scie. 22, 1 9 (1955)

(1967.9.11 ·受付) 